UDC 332.1:711

JEL Classification: R10;030

\title{
A METHODOLOGICAL APPROACH TO EVALUATING THE PROGRESS OF THE IMPLEMENTATION OF THE SMART CITY CONCEPT IN UKRAINIAN CITIES
}

\author{
๑ 2019 POLIAKOVA O. YU., POZDNIAKOVA A. M.
}

UDC 332.1:711

JEL Classification: R10; 030

Poliakova O. Yu., Pozdniakova A. M.

\section{A Methodological Approach to Evaluating the Progress of the Implementation of the Smart City Concept in Ukrainian Cities}

Ukrainian cities are joining the global movement for digitalization. They have gradually started to use benefits of ICT, claiming their smartness and promoting newIy implemented technological solutions. However, till the date we do not have a commonly accepted definition or framework for measuring their success. Based on the reviewed international and national frameworks, there proposed a methodological approach to evaluating the progress of Ukrainian cities in implementing the Smart Sustainable City Framework. The research takes into account both the theoretical base (components and definitions of Smart Sustainable City defined by different scholars) and practical side (the available evaluation methodologies). The developed Framework comprises two stages: a) creation of conditions for concept building; b) actual measurement of sustainability and smartness of cities, each of which including several dimensions. The model uses 54 indicators, the data being taken from both official statistical sources and survey data. The methodology has been used to measure the index of six selected Ukrainian cities that are considered quite progressive in terms of ICT usage and smart solution implementation. The results reveal that cities with officially adopted relevant strategies typically demonstrate better results than those that implement innovations on an ad-hoc basis.

Keywords: smart sustainable city, digitalization, ICT, innovations, triple bottom line, strategy.

DOI: https://doi.org/10.32983/2222-0712-2019-1-74-82

Fig.: 4. Tbl.: 2. Formulae: 2. Bibl.: 15.

Poliakova Olha Yu. - Candidate of Sciences (Economics), Associate Professor, Head of the Sector of Macroeconomic Analysis and Forecasting of the Department of Macroeconomic Policy and Regional Development, Research Centre of Industrial Problems of Development of NAS of Ukraine (2 floor 1a Inzhenernyi Ln., Kharkiv, 61166, Ukraine

E-mail: polya_o@ukr.net

ORCID: 0000-0001-8207-3198

Researcher ID: F-3460-2015

spin: 5449-6644

Pozdniakova Anna M. - Postgraduate Student, Research Centre of Industrial Problems of Development of NAS of Ukraine (2 floor 1a Inzhenernyi Ln., Kharkiv, 61166, Ukraine

E-mail:mira37cle@gmail.com

УДК 332.1:711

JEL Classification: R10; 030

Полякова О. Ю., Позднякова А. М. Методичний підхід до очінки прогресу розбудови концепції «розумного сталого міста» в Україні

Українські міста долучаються до глобального руху цисрровізації. Поступово вони починають використовувати переваги IKT, заявляючи про свою розумність і просуваючи нові технологічні рішення. Проте i досі в Україні немає загальноприйнятого визначення "розумного сталого міста» та підходу для вимірювання успіху міст у даному напрямку. На підставі розглянутих міннародних і національних моделей у статті запропоновано методичний підхід для оцінки прогресу українських міст у розбудові концепції "розумного сталого міста». Взято до уваги як теоретичну базу (складові та визначення «розумних сталих міст» різних икіл), так і практичну (вже наявні методики оцінки). Для моделі оцінки українських міст виділино дві стадії із кількома складовими: а) створення умов для розбудови на основі концепції «розумного сталого міста»; б) безпосереднє вимірювання сталості та розумності міст. Модель використовує 54 показники, які отримані як з офіційних статистичних джерел, так і з даних опитувань. Перевірено нашу методологію на шести обраних містах України, які вважаються досить прогресивними з точки зору використання IKT і впровадження розумних рішень. Дослідження показує, що міста з офіційно прийнятими планами, як правило, демонструють кращі результати, ніж міста, які впроваджують інноваиії хаотично.
УДК 332.1:711

JEL Classification: R10; 030

Полякова О. Ю., Позднякова А. М. Методический подход к оценке прогресса реализации концепции "умного устойчивого города" в Украине

Украинские города присоединяются к глобальному движению иифровизации. Постепенно они начинают использовать преимущества ИКТ, заявляя о своей разумности и продвигая новые технологические реше ния. Однако до сих пор в Украине нет общепринятого определения "умного устойчивого города» и подхода для измерения успеха городов в данном направлении. На основании рассмотренных международных и национальных моделей в статье предложен методический подход для оценки прогресса украинских городов на пути имплементации кониепиии «умного устойчивого города». Принято во внимание как теоретическая база (составляющие и определения «умных устойчивых городов» разных школ), так и практическая (уже имеющиеся методики оценки). Для модели оценки украинских городов выделены две стадии с несколькими составляющими: а) создание условий для развития на основе концепции "умных устойчивых городов»; б) непосредственное измерение устойчивости и разумности городов. Модель использует 54 показателя, полученных как из официальных статистических источников, так и по данным опросов. Наша методология проверена на шести избранных городах Украины, которые считаются доста точно прогрессивными с точки зрения использования ИКТ и внедрения разумных решений. Исследование показывает, что города с офици- 
Ключові слова: «розумне стале місто», діджиталізація, ІКТ, інновації, модель потрійного критерію, стратегія.

Рис.: 4. Табл.: 2. Формул: 2. Бібл.: 15.

Полякова Ольга Юріївна - кандидат економічних наук, доцент, завідувач сектора макроекономічного аналізу та прогнозування відділу макроекономічної політики та регіонального розвитку, Науководослідний чентр індустріальних проблем розвитку НАН України (пров. Інженерний, 1a, 2 пов., Харків, 61166, Україна)

E-mail:polya_o@ukr.net

ORCID: 0000-0001-8207-3198

Researcher ID: F-3460-2015

spin: 5449-6644

Позднякова Анна Михайлівна - аспірант, Науково-дослідний центр індустріальних проблем розвитку НАН України (пров. Інженерний, 1a, 2 пов., Харків, 61166, Україна)

E-mail:mira37cle@gmail.com ально принятыми планами, как правило, демонстрируют лучшие результаты, чем города, которые внедряют инновации хаотично.

Ключевые слова: "умный устойчивый город», диджитализация, ИКТ, инновации, модель тройного критерия.

Рис.: 4. Табл.: 2. Формул: 2. Библ.: 15.

Полякова Ольга Юрьевна - кандидат экономических наук, дочент, заведующий сектором макроэкономического анализа и прогнозирования отдела макроэкономической политики и регионального развития, Научно-исследовательский центр индустриальных проблем развития НАН Украины (пер. Инженерный, 1a, 2 эт., Харьков, 61166, Украина)

E-mail:polya_o@ukr.net

ORCID: 0000-0001-8207-3198

Researcher ID: F-3460-2015

spin: $5449-6644$

Позднякова Анна Михайловна - аспирант, Научно-исследовательский центр индустриальных проблем развития НАН Украины (пер. Инженерный, 1a, 2 эт., Харьков, 61166, Украина)

E-mail:mira37cle@gmail.com
Nowadays, using information and communications technology (ICT) is considered to be one of the ways that can help society to overcome challenges posed by rapid urbanization, in particular: high level of pollution, congestion, increasing demand for scarce resources, demographic changes, migration, ageing of population, and related demand for smart health solutions.

Smart cities that use new technologies and data in their decision-making processes have managed to reduce the crime incidents rate by $30-40 \%$, decrease water consumption by 20 $30 \%$, and accelerate emergency response time by $20-35 \%$ [1].

However, smart cities represent a deeper and more multidisciplinary model which aims to unite and use the synergy of the physical, digital, and human components. The concept becomes a trend of the $21^{\text {st }}$ century among business and political stakeholders, since more and more cities claim to be smart and sustainable.

For example, according to IHS Technology, by 2025 there will be at least 88 smart cities worldwide [2]. They define smart cities as "cities that have deployed - or are currently piloting the integration of information, communications, and technology (ICT) solutions across three or more different functional areas of a city (mobile and transport, energy and sustainability, physical infrastructure, governance, safety, and security) [2]. While according to a new report from Navigant Research, there are more than 250 smart city projects from 178 cities worldwide, with the majority focusing on government and energy initiatives [3].

In the recent years the concept has evolved from the purely technology-led approach (Smart City 1.0) towards inclusive and sustainable human-centered framework (Smart City 3.0).

Analysis of recent researches and publications. The topic has been actively studied and developed by many prominent academic economists, including B. Cohen, R. Giffinger, P. Lombardi, H. Schaffers, M. Rosenthal, and others. Many famous institutions have taken part in the establishment of different methodologies that allow measuring sustainability and smartness of cities, including, IESE, ITU, OECD, and UN-Habitat along with such private institutions Arcadis, Ericsson, and Huawei.

Since 2014 there has been a great movement towards the formal acceptance of smart city strategies at the municipal level along with developing national roadmaps in some countries.

In Ukraine, as in many other countries worldwide, the concept is developing rather from the bottom than from the top and is characterized by the lack of conceptualization. Cities lack formally adopted definition and framework to measure their progress and success.

Thus, we see a need in an academic approach to developing a measurement framework for Ukrainian cities.

The aim of the article. The article aims at suggesting a methodological approach to evaluating the progress and results of the implementation of the Smart Sustainable City concept in Ukraine, based on the systematization of the measurement systems and indexes that are available worldwide, with consideration for both the national context and international best practices.

Within the research we reviewed international frameworks (Arcadis Sustainable City Index, Cities in Motion Index, Network Society City Index, City Prosperity Index, Global Power City Index, European Smart Cities, Smart City Wheel by Boyd Cohen, as well as CITYKeys performance measurement framework) and national ones (Smart Cities (Portugal), India Liveability Index, Australia's National Cities Performance Framework, and Smart City Concept (Russia). This has allowed identifying similar components and elaborating the approach to developing the Ukrainian national framework, which was used to measure the index for six selected cities.

In the course of the research there used the methods of theoretical, logical, and systems analysis of the literature (methodologies for calculating the index, relevant reviews, plans, and strategies) along with the methods of comparative analysis, generalization, and statistical analysis. 
International experience. The International Telecommunication Union defines a smart sustainable city as "an innovative city that uses ICTs and other means to improve quality of life, efficiency of urban operation and services, and competitiveness, while ensuring that it meets the needs of present and future generations with respect to economic, social and environmental aspects" [4].
The conducted analysis of the academic and business cases revealed that typically the theoretical and practical area very broadly include the following components: People, Planet, Profit, Governance and ICT in different combinations and weights. Fig. 1 presents a more detailed summary of the components and the supporting entities.

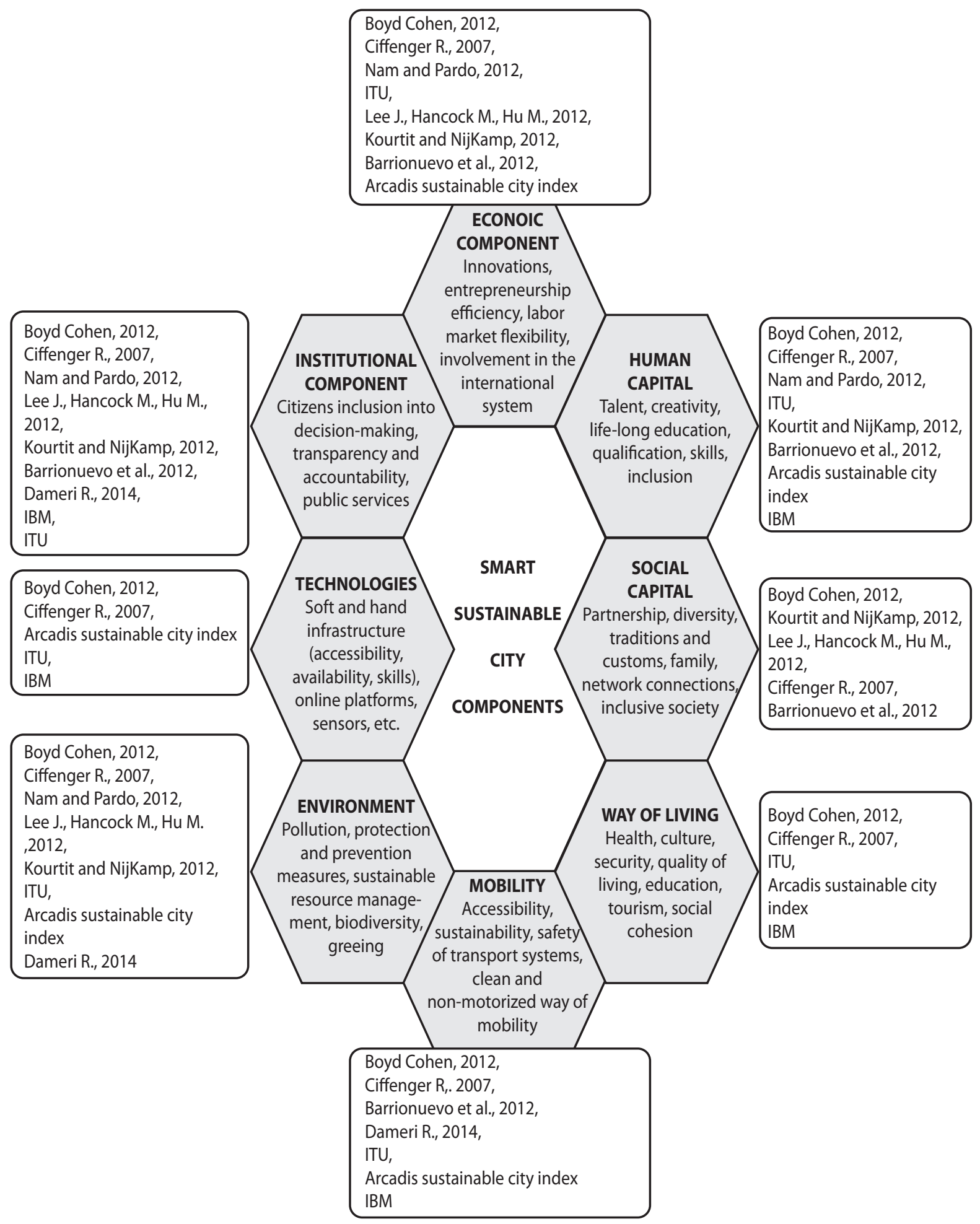

Fig. 1. Components of Smart Sustainable City Framework [5] 
For further research, we selected several international and national metrics based on the following criteria: (1) the index covers at least three dimensions: social, economic, ecological one; (2) the methodology has been applied in practice 1+ times; (3) the index is used at the city level; (4) ICT is presented either as a separate component or as one of the group indicators.

The research has revealed that different methodologies have similar limitations. For example, the lack of data at the city level and the need to use average values, which can lead to certain distortions; comparison of data over several years is quite doubtful due to changes in the methodology that occur regularly; coverage is typically limited to large cities, ignoring small and medium-sized ones.

The considered indexes use different approaches for data normalization (i.e. min-max approach, DP2 technique, Z-Score, etc.) and different models for estimation of the index (using the same weight or different weights for the components). The summarized results of the research are presented in Tbl. 1.

Table 1

Indexes for measuring smartness and sustainability of cities

\begin{tabular}{|c|c|c|c|c|c|}
\hline Name & Developer & $\begin{array}{c}\text { Year/ } \\
\text { frequency }\end{array}$ & $\begin{array}{l}\text { Number } \\
\text { of cities }\end{array}$ & Object of measurement & Components \\
\hline 1 & 2 & 3 & 4 & 5 & 6 \\
\hline \multicolumn{6}{|c|}{ International frameworks } \\
\hline $\begin{array}{l}\text { Arcadis Sustainable } \\
\text { Cities Index }\end{array}$ & $\begin{array}{l}\text { Arcadis and Centre } \\
\text { for Economic and } \\
\text { Business Research }\end{array}$ & $\begin{array}{l}2015 \text { / ev- } \\
\text { ery year }\end{array}$ & 100 & $\begin{array}{l}\text { Urban sustainability that } \\
\text { encompasses measures of } \\
\text { the social, environmental and } \\
\text { economic health of cities }\end{array}$ & $\begin{array}{l}\text { Social, economic, envi- } \\
\text { ronmental components }\end{array}$ \\
\hline $\begin{array}{l}\text { Cities in Motion } \\
\text { Index }\end{array}$ & IESE & $\begin{array}{l}2013 / \mathrm{ev}- \\
\text { ery year }\end{array}$ & 181 & $\begin{array}{l}\text { Future sustainability of the } \\
\text { world's largest cities as well } \\
\text { as the quality of life of their } \\
\text { inhabitants }\end{array}$ & $\begin{array}{l}\text { Human capital, social } \\
\text { cohesion, economy, } \\
\text { international outreach, } \\
\text { public management, } \\
\text { governance, mobility, } \\
\text { environment, urban plan- } \\
\text { ning, technologies }\end{array}$ \\
\hline $\begin{array}{l}\text { Networked Society } \\
\text { City Index }\end{array}$ & Ericsson & $\begin{array}{l}2011 / \text { ev- } \\
\text { ery year }\end{array}$ & 41 & $\begin{array}{l}\text { ICT maturity and triple bot- } \\
\text { tom line effects derived from } \\
\text { ICT }\end{array}$ & $\begin{array}{l}\text { Triple-bottom line and } \\
\text { ICT (availability, usage, } \\
\text { accessibility) }\end{array}$ \\
\hline $\begin{array}{l}\text { City Prosperity Index } \\
\text { (CPI) }\end{array}$ & UN-Habitat & $\begin{array}{l}2012, \\
2015\end{array}$ & 60 & $\begin{array}{l}\text { The way cities create and } \\
\text { distribute socio-economic } \\
\text { benefits or prosperity and } \\
\text { the overall achievements of } \\
\text { the city }\end{array}$ & $\begin{array}{l}\text { Productivity, quality of } \\
\text { life, infrastructure, eq- } \\
\text { uity and social inclusion, } \\
\text { environmental sustain- } \\
\text { ability, governance and } \\
\text { legislation }\end{array}$ \\
\hline $\begin{array}{l}\text { European Smart } \\
\text { Cities }\end{array}$ & $\begin{array}{l}\text { Vienna University of } \\
\text { Technology }\end{array}$ & $\begin{array}{l}2007 \\
2013 \\
2014 \\
2015\end{array}$ & 90 & $\begin{array}{l}\text { City functioning in six dimen- } \\
\text { sions (smart economy, smart } \\
\text { mobility, smart environment, } \\
\text { smart people, smart living, } \\
\text { smart governance) }\end{array}$ & $\begin{array}{l}\text { Smart economy, smart } \\
\text { mobility, smart environ- } \\
\text { ment, smart people, } \\
\text { smart living, smart gov- } \\
\text { ernance }\end{array}$ \\
\hline $\begin{array}{l}\text { Global Power City } \\
\text { Index (GPCI) }\end{array}$ & $\begin{array}{l}\text { The Institute for } \\
\text { Urban Strategies at } \\
\text { the Mori Memorial } \\
\text { Foundation }\end{array}$ & $\begin{array}{l}2008 / \text { ev- } \\
\text { ery year }\end{array}$ & 44 & $\begin{array}{l}\text { Cities magnetism, their abil- } \\
\text { ity to attract creative people } \\
\text { and businesses from different } \\
\text { countries of the world }\end{array}$ & $\begin{array}{l}\text { Economy, R\&D, cultural } \\
\text { interaction, liveability, en- } \\
\text { vironment, accessibility }\end{array}$ \\
\hline $\begin{array}{l}\text { CITYKeys Perfor- } \\
\text { mance Measure- } \\
\text { ment Framework }\end{array}$ & $\begin{array}{l}\text { Partnership of } \\
\text { research institutes } \\
\text { and } 5 \text { European } \\
\text { cities }\end{array}$ & 2017 & - & $\begin{array}{l}\text { Monitoring and comparing } \\
\text { the implementation of Smart } \\
\text { City Solutions, with the objec- } \\
\text { tive of speeding up the transi- } \\
\text { tion to low carbon, resource } \\
\text { efficient cities }\end{array}$ & $\begin{array}{l}\text { People, planet, prosper- } \\
\text { ity, governance and } \\
\text { propagation }\end{array}$ \\
\hline \multicolumn{6}{|c|}{ National frameworks } \\
\hline $\begin{array}{l}\text { Smart Cities (Por- } \\
\text { tugal) }\end{array}$ & $\begin{array}{l}\text { Private non-profit } \\
\text { innovation center } \\
\text { INTELI }\end{array}$ & 2012 & 40 & Urban intelligence & $\begin{array}{l}\text { Innovation, sustainability, } \\
\text { social inclusion, gover- } \\
\text { nance and connectivity }\end{array}$ \\
\hline
\end{tabular}


End tbl. 1

\begin{tabular}{|l|l|c|c|l|l|}
\hline \multicolumn{1}{|c|}{$\mathbf{1}$} & \multicolumn{1}{|c|}{$\mathbf{2}$} & $\mathbf{3}$ & $\mathbf{4}$ & \multicolumn{1}{c|}{$\mathbf{5}$} & \multicolumn{1}{c|}{$\mathbf{6}$} \\
\hline $\begin{array}{l}\text { National Cities } \\
\text { Performance Frame- } \\
\text { work (Australia) }\end{array}$ & $\begin{array}{l}\text { The Australian } \\
\text { Government }\end{array}$ & 2017 & 21 & $\begin{array}{l}\text { Tracking the progress and } \\
\text { performance of the cities us- } \\
\text { ing the predefined targets }\end{array}$ & $\begin{array}{l}\text { Infrastructure and invest- } \\
\text { ment, jobs and skills, live- } \\
\text { ability and sustainability, } \\
\text { innovation and digital } \\
\text { opportunities }\end{array}$ \\
\hline $\begin{array}{l}\text { Liveability Index } \\
\text { (India) }\end{array}$ & $\begin{array}{l}\text { Ministry of Urban } \\
\text { Development of } \\
\text { India }\end{array}$ & 2017 & 116 & $\begin{array}{l}\text { Evaluating the degree of "live- } \\
\text { ability" of the cities }\end{array}$ & $\begin{array}{l}\text { Institutional, social, } \\
\text { economic and physical } \\
\text { components }\end{array}$ \\
\hline
\end{tabular}

Source: [5]

There are also principles to follow while developing key performance indicators (KPIs):

1) Comprehensiveness: indicators should cover all the aspects of smart sustainable cities.

2) Comparability: the framework should include indicators that must be comparable over time and space.

3) Availability: the data, both current and historic should be either available or easy to collect.

4) Independence: the overlap of KPIs should be avoided as much as possible.

5) Simplicity: the concept should be simple to understand and follow.

6) Timeliness: prompt reaction to changes in the world for corresponding adjustment of the methodology [4].

Ukrainian context. Ukrainian cities only begin their path in developing the concept of Smart City. Thus, as in many other countries, we do not have a commonly accepted definition for a smart city or a methodology for determining smartness and sustainability of cities.

However, some of the internal studies allow measuring one or several components of the concept. One of the main issues is the fact that many indexes are estimated only once or on an ad-hoc basis and do not allow to see the dynamic changes.

Below we consider several indexes existing in Ukraine:

- Transparent Cities Ranking, which is prepared by the Transparency International for 100 Ukrainian cities. It evaluates transparency of the cities, amount of proactively provided information to citizens, quality of preventive measures against corruption, and openness of information for citizens [6].

- Top 55 Ukrainian Cities to Live (the ranking of comfortability of Ukrainian cities, which has been calculated by the Focus magazine since 2007). It covers six categories: economy, safety of living, mobility, quality of services, environment, and public opinion [7].

- The Poll of International Republican Institute that studies satisfaction of citizens with the quality of services and opportunities provided in cities [8].

- Index of City Democracy conducted by the experts from USAID "Citizens in action". Which allows to measure how the largest Ukrainian cities correspond to the European standards of openness, transparency and accountability. It's conducted annually starting from 2016 [9].
- The Index of Cultural and Creative Capital of Ukrainian Cities, which was ordered by the Kyiv Smart City initiative and presented in 2018 by a think tank CEDOS. The index aims to measure the potential of the cities to develop cultural and creative industries [10]. It is based on three groups of indicators (1) vitality of cultural life; (2) development of cultural and creative industries; (3) conditions that promote the development of culture and creativity [10].

Based on the conducted research and available indexes, we would like to suggest a framework for Ukrainian cities to evaluate their progress in developing the concept of Smart City. The process of evaluation can be split in two steps that correspond to the stages cities undergo: a) creation of conditions for the concept development; b) actual measurement of sustainability and smartness of cities.

The first (preparation) stage can be broadly described as provision of technical and organizational support. It implies that people should have devices (PCs, smartphones, laptops, etc.) available and Internet access. Moreover, the state should provide citizens with the access to open data, since this allows creating smart applications and solutions to improve the quality of life and services rendered by the government. We will call this component "Digitalization".

Another part of the preparation stage ("Conceptualization") deals with the organizational component. It implies the availability of a smart city strategy, platform for communication and feedback, establishment of a responsible body, etc.

The second stage measures actual people-friendliness, sustainability and smartness of cities as living environment. The core idea is a human-centered approach, which can be disclosed through the following scheme (Fig. 2).

- "Citizens quality of life" axis. It concerns satisfaction of all basic human needs (housing, food, clothes, health services, etc.), provides opportunities for revealing human potential (education, launching business, job opportunities) and opportunities for spiritual enrichment (cultural sphere, travel opportunities, etc.).

- "Citizen - authority" axis. It evaluates the quality of relations between citizens and authorized bodies (transparency, availability of services, accountability etc.) as well as the civil activity and engagement of the inhabitants.

- "Citizen - environment" axis. This dimension covers safe existence of citizens and their impact on the environment. 
Preconditions (1/2)

Technological and organizational provision

\begin{tabular}{|c|c|}
\hline Digitalization & Conceptualization \\
\hline $\begin{array}{l}\text { Devices availability, } \\
\text { Internet access, } \\
\text { Internet usage, } \\
\text { Open data } \\
\text { - }\end{array}$ & $\begin{array}{l}\text { Strategy, } \\
\text { Platform, } \\
\text { Supporting mechanism, } \\
\text { Partnership } \\
\end{array}$ \\
\hline
\end{tabular}

Impact (1/2)

Measuring the smartness, comfort and sustainability of cities

\begin{tabular}{|c|c|c|c|}
\hline Quality of life & Citizen - authority & Citizen - environment & City in the system of cities \\
\hline $\begin{array}{l}\text { Basic needs, } \\
\text { Human potential } \\
\text { realization, } \\
\text { Cultural and spiritual } \\
\text { enrichrnent }\end{array}$ & $\begin{array}{l}\text { Citizen participation, } \\
\text { Quality and availability } \\
\text { of services, } \\
\text { Transparency }\end{array}$ & $\begin{array}{l}\text { Pollution, } \\
\text { Utilization of waste, } \\
\text { Crime rate, } \\
\text { Road traffic safety }\end{array}$ & $\begin{array}{l}\text { City attractiveness, } \\
\text { Innovations, } \\
\text { Openness }\end{array}$ \\
\hline
\end{tabular}

Fig. 2. Components of Ukrainian Smart City Index

- "City in a system of cities" axis. It evaluates attractiveness of a city for people who do not reside in it (attractiveness for tourists or business), including exchange of knowledge and experience with other cities.

To build the index we used the following sources of information:

- official statistical data: Statistical Yearbook of the State Statistics Service, statistics of the Ukrainian Center for Education Quality Assessment (UCEQA), data of the Ukrainian Intellectual Property Institute (Ukrpatent), etc.;

- survey and research results: the project of Transparency International "Transparent Cities", polls of the International Republican Institute, Top 55 Ukrainian Cities to Live, Ease of Doing Business Index, etc.;

- data from online services: olx.ua, dom.ria, bigidea, etc.

The index is built through the aggregation (using arithmetic mean) of components (Fig. 3).

Currently all components have the same weight since we do not have any grounds to assign different weights for components right now.

Since all the components have different measurement systems, the normalization procedure is needed. For this purpose we have selected Min-Max method:

$$
I=\frac{x-x_{\min }}{x_{\max }-x_{\min }}
$$

As a result, all the indicators will take values between 0 and 1 . It should be taken into account that some indicators have negative impact, that's why a different approach should be used for them:

$$
I^{\prime}=\frac{x_{\max }-x}{x_{\max }-x_{\min }}
$$

Thus, the developed two-component model comprises six sub-components which are calculated with the use of 54 indicators.

The methodology has been applied to calculate the index for six selected cities (Kharkiv, Kyiv, Odesa, Lviv, Vinnytsia, Dnipro), which are quite often highlighted in the media in the context of their innovative approaches to solving urban issues using technologies.

We reviewed two time periods, including 2016 and 2017, the missing data being replaced with the data available at the regional level.

Results of the calculations are presented in Table 2.

Kyiv and Lviv are the leaders of the ranking. Kyiv developed Smart City Concept back in 2015, in 2017 it was adopted at the official level and closer cooperation was established among the municipality, civil and business sectors. The city has a platform for communication, feedback and constant updating [11]. A number of successful projects have been already implemented in the city:

Citizen Budget, e-petitions, participatory budgeting, virtual queuing, etc. [11].

In 2016 Lviv adopted Digital Transformation Program for 2016-2020 [12]. Moreover, the city has recently started holding an annual Smart City Forum $\left(451^{\circ} \mathrm{E}\right)$ to get acquainted with the experience of implementing the Smart City Concept in other cities of the world and facilitate implementing the concept of Lviv Smart City.

The third place is occupied by Vinnytsia, which is one of the pioneering cities in e-gov smart solutions, e.g., Citizens 

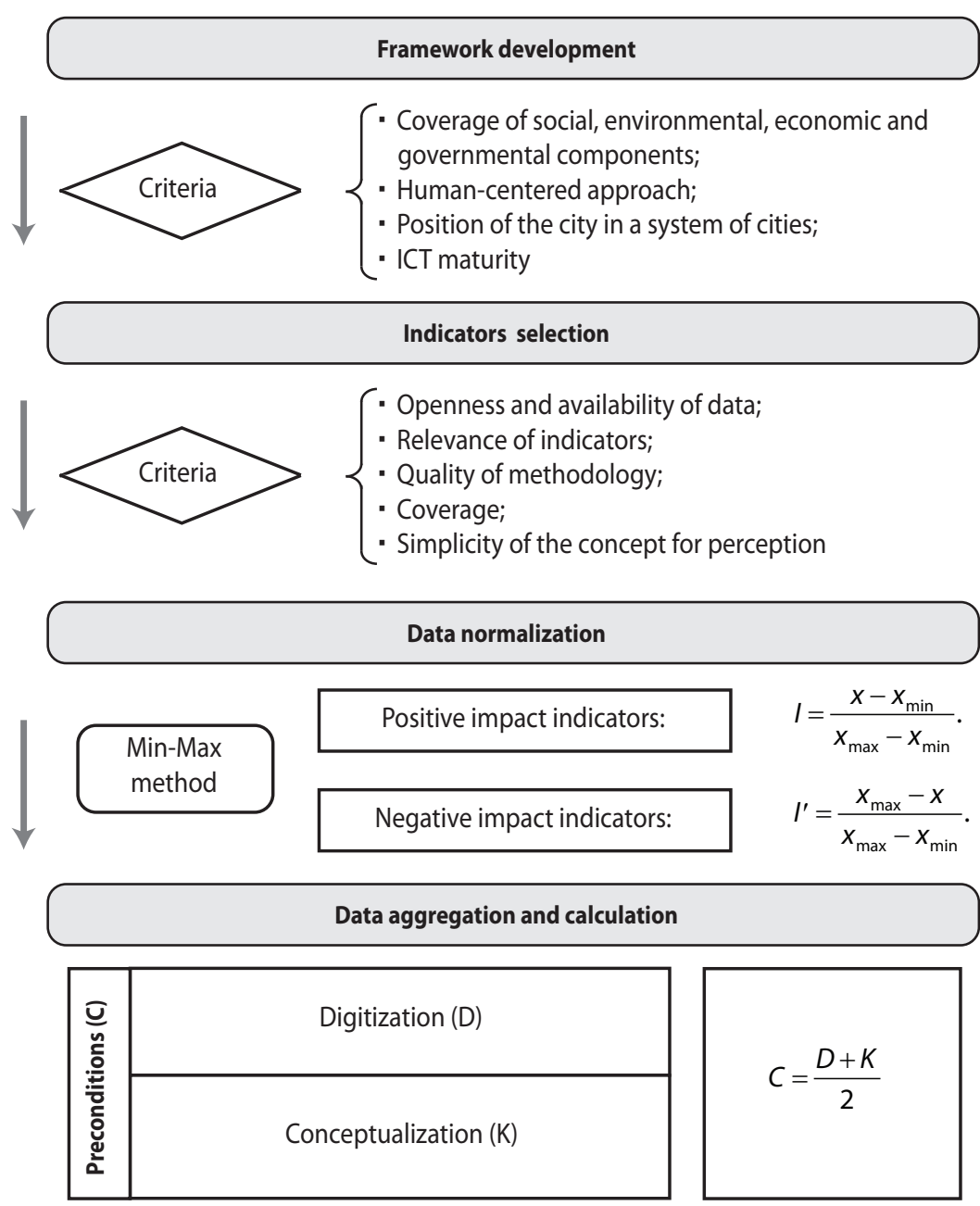

\begin{tabular}{|c|c|}
\hline \multirow{4}{*}{ 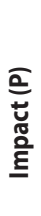 } & Quality of life (SE) \\
\hline & «Citizen - authority» (G) \\
\hline & «Citizen - environment» (PH) \\
\hline & «City in a system of cities» (I) \\
\hline
\end{tabular}
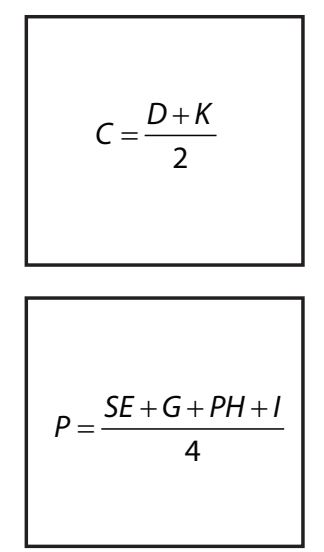

Two components, six sub-components

\section{4 indicators}
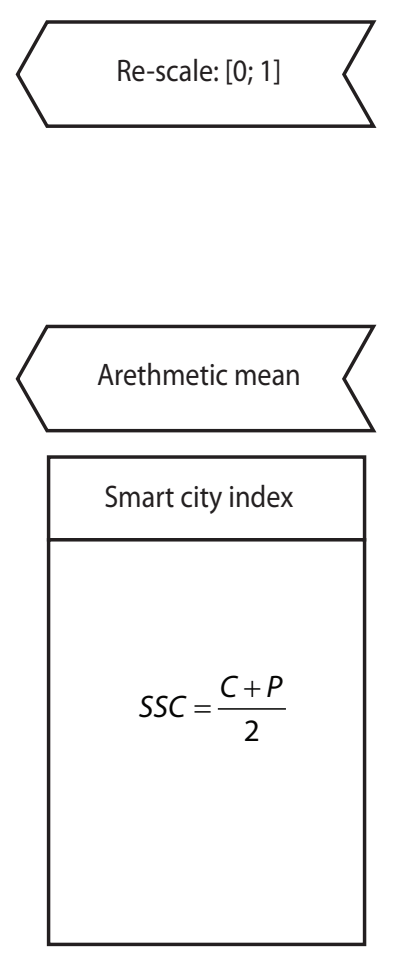

Fig. 3. Algorithm of the Smart City Index development

Table 2

Smart city index, results

\begin{tabular}{|l|c|c|c|c|c|c|c|c|c|c|c|c|}
\hline & \multicolumn{2}{|c|}{ Kharkiv } & \multicolumn{2}{c|}{ Kyiv } & \multicolumn{2}{c|}{ Lviv } & \multicolumn{2}{c|}{ Dnipro } & \multicolumn{2}{c|}{ Vinnytsia } & \multicolumn{2}{c|}{ Odessa } \\
\cline { 2 - 16 } & $\mathbf{2 0 1 6}$ & $\mathbf{2 0 1 7}$ & $\mathbf{2 0 1 6}$ & $\mathbf{2 0 1 7}$ & $\mathbf{2 0 1 6}$ & $\mathbf{2 0 1 7}$ & $\mathbf{2 0 1 6}$ & $\mathbf{2 0 1 7}$ & $\mathbf{2 0 1 6}$ & $\mathbf{2 0 1 7}$ & $\mathbf{2 0 1 6}$ & $\mathbf{2 0 1 7}$ \\
\hline Digitalization & 0.43 & 0.57 & 1.00 & 1.00 & 0.53 & 0.46 & 0.48 & 0.66 & 0.30 & 0.38 & 0.58 & 0.63 \\
\hline Conceptualization & 0.00 & 0.50 & 1.00 & 1.00 & 0.5 & 0.75 & 0.25 & 0.50 & 0.25 & 0.50 & 0.00 & 0.00 \\
\hline PRECONDITIONS & 0.21 & 0.53 & 1.00 & 1.00 & 0.52 & 0.61 & 0.37 & 0.58 & 0.27 & 0.44 & 0.29 & 0.32 \\
\hline - Citizen - authority & 0.44 & 0.33 & 0.65 & 0.72 & 0.75 & 0.73 & 0.33 & 0.54 & 0.74 & 0.89 & 0.28 & 0.42 \\
\hline - Citizen - environment & 0.65 & 0.67 & 0.42 & 0.39 & 0.69 & 0.61 & 0.26 & 0.37 & 0.82 & 0.86 & 0.50 & 0.49 \\
\hline Quality of life & 0.40 & 0.35 & 0.73 & 0.68 & 0.45 & 0.38 & 0.34 & 0.27 & 0.35 & 0.36 & 0.20 & 0.19 \\
\hline City in a system of cities & 0.45 & 0.36 & 0.98 & 0.94 & 0.44 & 0.42 & 0.32 & 0.34 & 0.17 & 0.17 & 0.28 & 0.31 \\
\hline IMPACT & 0.48 & 0.43 & 0.70 & 0.68 & 0.58 & 0.54 & 0.31 & 0.38 & 0.52 & 0.57 & 0.31 & 0.35 \\
\hline INDEX & 0.35 & 0.48 & 0.85 & 0.84 & 0.55 & 0.57 & 0.34 & 0.48 & 0.40 & 0.50 & 0.30 & 0.34 \\
\hline
\end{tabular}

Source: developed by the authors 

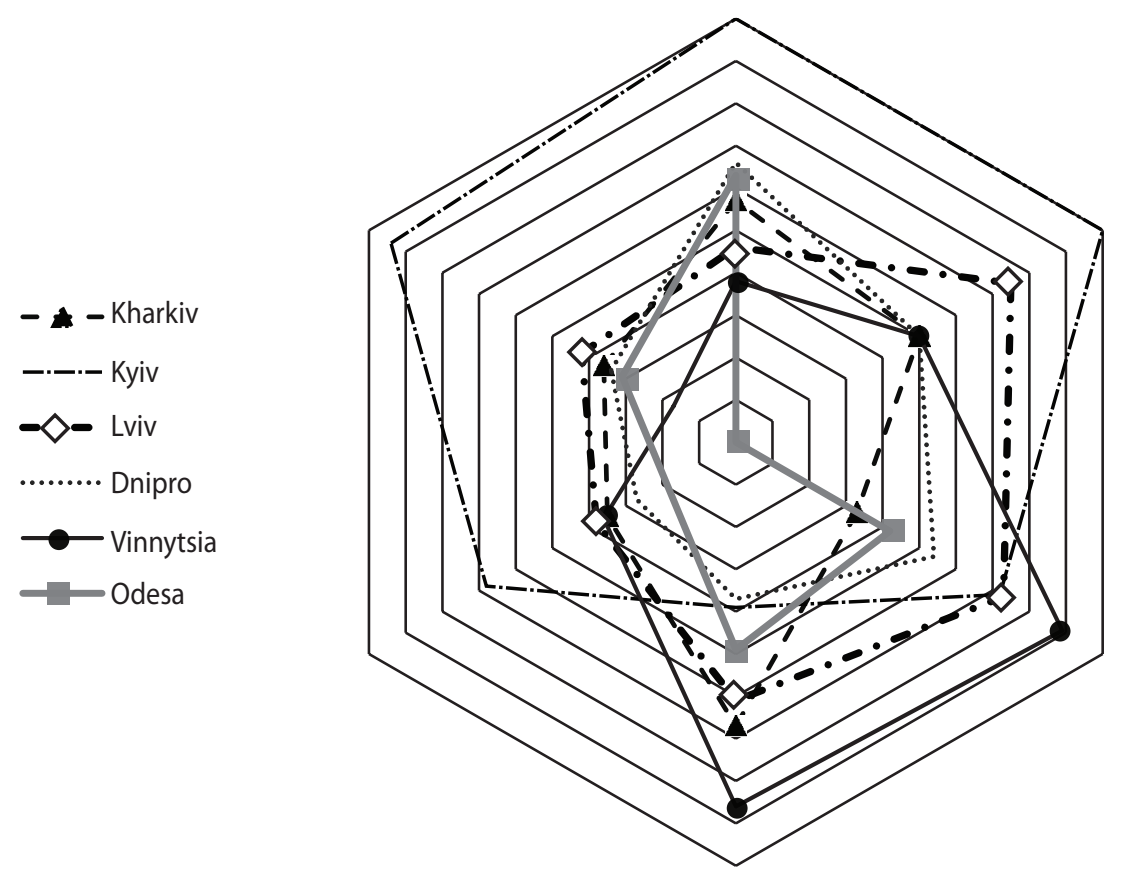

Fig. 4. Component structure of the Ukrainian Index

portal was launched back in 2013. However, the Digital Agenda was accepted not long ago, in 2018 [13].

Kharkiv and Dnipro are sharing the fourth place. Both do not have a formally adopted smart city strategy but possess a great innovative potential. Recently, in both cities, specialized institutions have been established, which should contribute greatly to Smart City Concept development. We expect the ranks of these cities to improve within the next year.

In Figure 4, there visualized the component structure of the developed Index to compare the analyzed cities. The leading positions in the axes "Citizen - authority" and "Citizen environment" is occupied by Vinnytsia.

Conclusions. According to Global Open Data Index, only $20 \%$ of data is open in Ukraine [14]. And only $58 \%$ of Ukraine's population use the Internet, most of them living in the urban area [15]. However, in 2017 the first national competition of IT innovative projects was conducted in the country (OpenDataChallenge), which has become an annual tradition.

Nevertherless, there are still things Ukraine needs to work on to make ICT beneficial for its citizens. One of the important tasks is taking measures against threats to privacy and cybercrime.

However, many Ukrainian cities have already implemented smart solutions and practices, aiming to become more citizen-friendly and resilient.

Thus, we have analyzed several international and national methodologies to measure smartness and sustainability of cities with the purpose of suggesting a model suitable for Ukrainian cities.

In our opinion, as for now, the Smart Sustainable City Framework should include the preparation stage and the stage of evaluating actual results. In the future, when Internet access, device availability, and open data will become ordinary things for all cities, the preparation stage can be omitted.
Till the date, hardly any city in Ukraine has succeeded in terms of Conceptualization, since only the city of Kyiv has Smart City Strategy and a functioning platform for communication and feedback.

In general, digital transformation and innovations, as well as the movement towards the open data, will allow involving even more indicators for the analysis, thus the methodology for 2018 needs revising in order to be relevant.

Meanwhile, the current results show that cities that have already officially adopted plans to build a digital society and use technologies in different areas of life score better than those that implement innovations on an ad-hoc basis. In addition, a crucial role is played by ICT maturity of the society as well as mechanisms for working with people who cannot benefit from the technological advancements due to certain reasons.

\section{LITERATURE}

1. Smart Cities: Digital Solutions for a More Livable Future // McKinsey\&Company. June 2018. URL: https://www.mckinsey.com

2. Smart Cities to Rise Fourfold in Number from 2013 to 2025 // IHS Markit. July 2014. URL: https://news.ihsmarkit.com/pressrelease/design-supply-chain-media/smart-cities-rise-fourfoldnumber-2013-2025

3. More than 250 Smart City Projects Exist in 178 Cities Worldwide // Navigant Research. March 2017. URL: https://www. navigantresearch.com/news-and-views/more-than-250-smartcity-projects-exist-in-178-cities-worldwide

4. Focus Group on Smart Sustainable Cities // ITU-T. 2014. Smart sustainable definitions. URL: http://www.itu.int/en/ITU- T/ focusgroups/ssc/Pages/default.aspx

5. Pozdniakova A. M. Developing an approach to measure smartness and sustainability of Ukrainian cities. Business Inform. 2018. № 10. P. 116-125. URL: http://www.businessinform.net/sear $\mathrm{ch} /$ ?qu=\%D0\%9F\%D0\%BE\%D0\%B7\%D0\%B4\%D0\%BD\%D1\%8F\% D0\%BA\%D0\%BE\%D0\%B2\%D0\%B0\&x=0\&y=0 
6. Рейтинг прозорості 100 найбільших міст України. URL: https://transparentcities.in.ua/infographics/rejtynh-prozorosti100-najbilshyh-mist-ukrajiny/

7. Бабенко М., Батурин А., Гордейчик Е., Романюк Е. Города и люди. Рейтинг комфортности украинских городов // Фокус. 07.08.17. URL: https://focus.ua/ratings/377768/

8. Рейтинги міст України: Четверте Всеукраїнське муніципальне опитування. URL: http://ratinggroup.ua/research/ regions/chetvertyy_vseukrainskiy_municipalnyy_opros.html

9. Index of city democracy. URL: http://www.ucipr.org.ua/ index.php?option=com_content\&view=article\&id=417:ndeksdemokratichnost $-\mathrm{m}$-st\&catid $=16 \&$ lang $=$ ua\&ltemid $=186$

10. Індекс культурного та креативного потенціалу міст України. URL: https://www.kyivsmartcity.com/news-initiative/ index-of-creativity/

11. Kyiv Smart City. URL: https://www.kyivsmartcity.com/

12. Програма цифрового перетворення Львова. URL: https://www8.city-adm.lviv.ua/inTEAM/Uhvaly.nsf/(SearchForWeb)/ F5AAAA4163C74BBEC2257F7E0052E61F?OpenDocument

13. Програма цифрового розвитку Вінниці на 2018-2022. URL: http://www.vmr.gov.ua/Docs/CityCouncilDecisions/2018/\%E 2\%84\%961353\%2028-09-2018.pdf

14. Tracking the State of Open Government Data // Global open data index. URL: https://index.okfn.org/

15. Global Digital Report 2018 // We are Social. URL: https:// digitalreport.wearesocial

\section{REFERENCES}

Babenko, M. et al. "Goroda i lyudi. Reyting komfortnosti ukrainskikh gorodov" [Cities and people. Comfortableness rating of Ukrainian cities]. Fokus. 07.08.17. https://focus.ua/ratings/377768/

"Focus Group on Smart Sustainable Cities". ITU-T. 2014. Smart sustainable definitions. http://www.itu.int/en/ITU-T/focusgroups/ssc/Pages/default.aspx

"Global Digital Report 2018". We are Social. https://digitalreport.wearesocial

"Indeks kulturnoho ta kreatyvnoho potentsialu mist Ukrainy" [Index of Cultural and Creative Potential of Ukrainian Cities]. https:// www.kyivsmartcity.com/news-initiative/index-of-creativity/
"Index of city democracy". http://www.ucipr.org.ua/index.php?option=com_content $\&$ view $=$ article\&id $=417$ :ndeksdemokratichnost-m-st\&catid=16\&lang=ua\&ltemid $=186$

Kyiv Smart City. https://www.kyivsmartcity.com/

"More than 250 Smart City Projects Exist in 178 Cities Worldwide". Navigant Research. March 2017. https://www.navigantresearch.com/news-and-views/more-than-250-smart-city-projects-exist-in-178-cities-worldwide

"Prohrama tsyfrovoho peretvorennia Lvova" [Program of digital transformation of Lviv]. https://www8.city-adm.lviv.ua/inTEAM/Uhvaly.nsf/(SearchForWeb)/F5AAAA4163C74BBEC2257F7E 0052E61F?OpenDocument

"Prohrama tsyfrovoho rozvytku Vinnytsi na 2018-2022" [Vinnytsia Digital Development Program for 2018-2022]. http://www. vmr.gov.ua/Docs/CityCouncilDecisions/2018/\%E2\%84\%96135 3\%2028-09-2018.pdf

Pozdniakova, A. M. "Developing an approach to measure smartness and sustainability of Ukrainian cities". Business Inform. 2018. http://www.businessinform.net/search/?qu=\%D0\%9F\%D0 \%BE\%D0\%B7\%D0\%B4\%D0\%BD\%D1\%8F\%D0\%BA\%D0\%BE\%D0 $\% \mathrm{~B} 2 \% \mathrm{D} 0 \% \mathrm{~B} 0 \& \mathrm{x}=0 \& \mathrm{y}=0$

"Reitynh prozorosti 100 naibilshykh mist Ukrainy" [The transparency rating of the 100 largest cities in Ukraine]. https:// transparentcities.in.ua/infographics/rejtynh-prozorosti-100-najbilshyh-mist-ukrajiny/

"Reitynhy mist Ukrainy: Chetverte Vseukrainske munitsypalne opytuvannia" [Ratings of Ukrainian Cities: Fourth All-Ukrainian Municipal Poll]. http://ratinggroup.ua/research/regions/chetvertyy_vseukrainskiy_municipalnyy_opros.html

"Smart Cities to Rise Fourfold in Number from 2013 to 2025". IHS Markit. July 2014. https://news.ihsmarkit.com/press-release/ design-supply-chain-media/smart-cities-rise-fourfold-number2013-2025

"Smart Cities: Digital Solutions for a More Livable Future". McKinsey\&Company. June 2018. https://www.mckinsey.com

"Tracking the State of Open Government Data". Global open data index. https://index.okfn.org/ 